\section{Effect of Phosphorus Rates on Growth, Yield, and Postharvest Quality of Tomato in a Calcareous Soil}

\author{
Qiang Zhu' ${ }^{1}$ and Monica Ozores-Hampton \\ Southwest Florida Research and Education Center, Institute of Food and \\ Agricultural Sciences, University of Florida, Immokalee, FL 34142
}

\section{Yuncong Li}

Tropical Research and Education Center, Institute of Food and Agricultural Sciences, University of Florida, Homestead, FL 33031

\section{Kelly Morgan}

Southwest Florida Research and Education Center, Institute of Food and Agricultural Sciences, University of Florida, Immokalee, FL 34142

\section{Guodong Liu}

Horticultural Sciences Department, University of Florida, Gainesville, FL 32611

\author{
Rao S. Mylavarapu \\ Soil and Water Sciences Department, University of Florida, Gainesville, FL 32611
}

Additional index words. soil test interpretation, leaf tissue phosphorus concentration, plant biomass, regression models

\begin{abstract}
Phosphorous (P) has a significant role in root growth, fruit and seed development, and plant disease resistance. Currently, no $P$ fertilizer recommendations are available for vegetables grown on calcareous soils in Florida. The objective of this study was to evaluate the impact of different $P$ rates on leaf tissue $P$ concentration (LTPC), plant growth, biomass accumulation, fruit yield, and postharvest quality of tomato (Solanum lycopersicum L.) grown on a calcareous soil. The experiment was conducted with soils containing 13 to $15 \mathrm{mg} \cdot \mathrm{kg}^{-1}$ of $P$ extracted by ammonium bicarbonatediethylenetriaminepentaacetic acid (AB-DTPA). Phosphorus fertilizers were applied at rates of $0,29,49,78,98$, and $118 \mathrm{~kg} \cdot \mathrm{ha}^{-1}$ of $P$ before laying polyethylene mulch. Tomatoes were grown using drip irrigation during the winter seasons of 2014 and 2015 . No significant responses to $P$ rates were found in LTPC during both growing seasons. Plant height, stem diameter, and leaf chlorophyll content at 30 days after transplanting (DAT) were significantly affected by $P$ rates in 2015 , but not in 2014 . The responses of plant biomass were predicted by linear models at 60 DAT in 2014 and at 30 DAT in 2015. There were no significant differences in plant biomass at 95 DAT in both years. At the first and second combined harvest, the extralarge fruit yield was unaffected in 2014 , but predicted by a quadratic-plateau model with a critical rate of $75 \mathrm{~kg} \cdot \mathrm{ha}^{-1}$ in 2015 . The total season marketable yields (TSMY) and postharvest qualities were not significantly affected by $P$ rates in either year. Phosphorous rate of $75 \mathrm{~kg} \cdot \mathrm{ha}^{-1}$ was sufficient to grow a tomato crop during the winter season in calcareous soils with $13-15 \mathrm{mg} \cdot \mathrm{kg}^{-1}$ of AB-DTPAextractable $P$.
\end{abstract}

Phosphorus is an essential component of nucleic acids, phospholipids, and energy-rich phosphate compounds, thus, it plays crucial role in root growth, fruit and seed development,

Received for publication 7 June 2017. Accepted for publication 25 July 2017.

This research was partially funded by the Florida Department of Agriculture and Consumer Services (FDACS). We also thank DiMare Fresh Inc., Homestead, FL, for assistance in tomato harvesting and postharvest evaluation.

This article is based on a presentation given during the Annual Meeting of the Florida State Horticultural Society, which was held 4-6 June 2017, in Tampa FL.

${ }^{1}$ Corresponding author. E-mail: qiangzhuuf@ gmail.com. efficiency. Appropriate $\mathrm{P}$ fertilization is an important part of the BMP program.

In the United States, FL ranked first in fresh market tomato production with 11,331 ha harvested and a production value of US \$382 million in 2016 (U.S. Department of Agriculture, 2017). Phosphorus recommendations based on preplant soil test P (STP) have been established for tomato grown on acid-mineral soils in Florida (Freeman et al., 2014b). The recommended $P$ rates are 0 and $73 \mathrm{~kg} \cdot \mathrm{ha}^{-1}$ when the STP levels are high $(>45$ $\mathrm{mg} \cdot \mathrm{kg}^{-1}$ of Mehlich-3 extractable $\mathrm{P}$ or $>30$ $\mathrm{mg} \cdot \mathrm{kg}^{-1}$ of Mehlich-1 extractable P) and low $\left(\leq 25 \mathrm{mg} \cdot \mathrm{kg}^{-1}\right.$ of Mehlich-3 extractable P) or very low $\left(<10 \mathrm{mg} \cdot \mathrm{kg}^{-1}\right.$ of Mehlich-1 extractable P), respectively (Freeman et al., 2014b).

In Florida, there are 12,000 ha of calcareous soils used for vegetable production (U.S. Department of Agriculture, 2014). However, there are no official STP interpretations based on an effective extractant for calcareous soils. Ammonium bicarbonatediethylenetriaminepentaacetic acid (Soltanpour and Schwab, 1977), Mehlich-3 (Mehlich, 1984), and Olsen (Olsen et al., 1954) were commonly used as STP extractants in calcareous soils. In Florida, AB-DTPA was adopted with only a sufficient level of $10 \mathrm{mg} \cdot \mathrm{kg}^{-1}$ for vegetable growers ( $\mathrm{Li}$ et al., 2000). Nonetheless, vegetable growers tend to apply $\mathrm{P}$ to avoid fertilizer-related losses of yield and quality even though the STP is higher than that sufficient level. As a result, a large quantity of $\mathrm{P}$ accumulates in the soils. Lamberts et al. (1997) found reducing $\mathrm{P}$ rates to $37 \%$ to $50 \%$ of the standard rates used by local vegetable growers had no significant effects on tomato marketable yield. In addition, no yield responses of potato (Solanum tuberosum L.) and sweet corn (Zea mays L.) were observed in the calcareous soils to $\mathrm{P}$ application rates as high as 115 and $80 \mathrm{~kg} \cdot \mathrm{ha}^{-1}$, respectively (Li et al., 2000; Olczyk et al., 2003). Thus, P recommendations are not available for tomato grown on calcareous soils in Florida. Therefore, the objective of this experiment was to determine the optimum $\mathrm{P}$ rate for tomato production based on LTPC, plant growth, fruit yield, and postharvest quality in a calcareous soil.

\section{Materials and Methods}

ciency can stunt plant growth and reduce yield and quality. Over application of $\mathrm{P}$ fertilizers, at rates that exceed crop demand, will increase the risk of $\mathrm{P}$ losses from soil to water resources and impair water quality through eutrophication (von Wandruszka, 2006). Consequently, appropriate $P$ management is required to maintain crop yield and minimize environmental impacts. In response to the federal Total Maximum Daily Load mandate, the Florida Department of Agriculture and Consumer Services (FDACS) developed Best Management Practices (BMP) for vegetable crops in Florida (FDACS, 2015). One objective of the BMP program is to reduce the environmental impact of crop production on water quality by improving nutrient use
The study was conducted at the University of Florida (UF)/Institute of Food and Agricultural Sciences (IFAS)/Tropical Research and Education Center, Homestead, FL, during the winter seasons of 2014 (from 29 Oct. 2014 to 24 Mar. 2015) and 2015 (from 15 Oct. 2015 to 16 Feb. 2016). One field $\left(25^{\circ} 30^{\prime} 47^{\prime \prime} \mathrm{N} / 80^{\circ} 30^{\prime} 3^{\prime \prime} \mathrm{W}\right)$, covered by goosegrass (Eleusine indica) over ten years, was selected and plowed, and the grasses were incorporated into the soil (Loamyskeletal, carbonatic, hypothermic Lithic Udorthents). Sorghum-sudangrass (Sorghum bicolor $\times S$. bicolor var. sudanese) was then planted on 28 Aug. 2014, and the aboveground portions were removed from the field 
on 30 Sept. 2014 for purpose to reduce soil available $\mathrm{P}$ concentrations. Soil samples were collected before applying fertilizers in the growing season of 2014 and analyzed for basic physical and chemical properties (Table 1). In the growing season of 2015, preplant Mehlich-3-, AB-DTPA, and Olsen extractable $\mathrm{P}$ averaged 51, 13, and $19 \mathrm{mg} \cdot \mathrm{kg}^{-1}$, respectively.

Treatments included 0, 29, 49, 78, 98, and $118 \mathrm{~kg} \cdot \mathrm{ha}^{-1}$ of $\mathrm{P}$ and were arranged in a randomized complete block design with four replications. Nitrogen $(\mathrm{N})$ and potassium (K) were applied at constant rates of 224 $\mathrm{kg} \cdot \mathrm{ha}^{-1}$ of $\mathrm{N}$ and $149 \mathrm{~kg} \cdot \mathrm{ha}^{-1}$ of $\mathrm{K}$ for all treatments. Fertilizer application rates were selected according to the recommendations for tomato grown on acid-mineral soils as well as a previous pot study using the same calcareous soils (Zhu et al., 2016). Tomatoes were grown on bed with drip irrigation. Preplant dry fertilizers, including all $\mathrm{P}, 56$ $\mathrm{kg} \cdot \mathrm{ha}^{-1}$ of $\mathrm{N}$, and $56 \mathrm{~kg} \cdot \mathrm{ha}^{-1}$ of $\mathrm{K}$, were applied in two bands $(15 \mathrm{~cm}$ from the center of bed and $8 \mathrm{~cm}$ deep). Remaining $\mathrm{N}$ and $\mathrm{K}$ were supplied weekly from the first flowering to the first harvest stage via drip fertigation following UF/IFAS recommendations (Freeman et al., 2014b). Urea (46-0-0), triple superphosphate $(0-46-0)$, and potassium sulfate $(0-0-52)$ were used as $\mathrm{N}, \mathrm{P}$, and $\mathrm{K}$ dry fertilizers, respectively. Liquid fertilizers included N-Pact (26-0-0; Loveland Products Inc., Loveland, $\mathrm{CO})$ and LoKomotive (2-0 25; Loveland Products Inc.). Cultural practices used in the experiment were the same in both years except for the dates of fertilization, transplanting, and harvesting (Table 2). The tomato cultivar of Ridgerunner was selected because of its resistance to tomato yellow leaf curl virus, which severely affected tomato production in Florida. The pest control and irrigation management followed UF/IFAS recommendations (Freeman et al., 2014a). After the third harvest in the 2014 season, polyethylene mulch was removed, and tomato plants were incorporated into the soil, then the field was left fallow until the beginning of the 2015 season.

Weather data were obtained from a Florida Automated Weather Network station located $100 \mathrm{~m}$ away from the experimental field. Five to six most recently matured whole leaves plus petioles were collected from each plot at 30, 60, and 95 DAT to measure LTPC. Meanwhile, three plants from each plot were selected to measure plant height (from the ground to the tip of the plant), stem diameter (between the third and fourth nodes), and leaf chlorophyll content using the fifth leaf from the apex with a Soil Plant Analysis Development (SPAD) chlorophyll meter (SPAD-502; Konica Minolta Business Solutions Inc., Ramsey, NJ). One whole plant from each plot was also collected at 30,60, and 95 DAT, and the root, stem, leaf, and fruit portions were separated to measure the dry weight biomass of each part. All plant samples were oven-dried at $70{ }^{\circ} \mathrm{C}$ to constant weight. After drying, leaf tissue samples were ground to pass a $0.84-\mathrm{mm}$ sieve, digested by hydrochloric

Table 1. Characteristics of soils collected from the experimental site before applying fertilizers during the winter season of 2014.

\begin{tabular}{|c|c|c|}
\hline Gravel (>2 mm) (\%) & & 63 \\
\hline Clay $(\%)$ & & 3 \\
\hline Silt (\%) & & 5 \\
\hline Sand $(\%)$ & & 29 \\
\hline $\mathrm{pH}$ (water) & & 7.8 \\
\hline Electrical conductivity & & 248 \\
\hline Carbonate $\left(\mathrm{g} \cdot \mathrm{kg}^{-1}\right)$ & & 379 \\
\hline Organic matter $\left(\mathrm{g} \cdot \mathrm{kg}^{-1}\right.$ & & 57 \\
\hline Nitrate-nitrogen $(\mathrm{mg} \cdot \mathrm{k}$ & & 22 \\
\hline Ammonium-nitrogen & & 7 \\
\hline Total P $\left(\mathrm{mg} \cdot \mathrm{kg}^{-1}\right)$ & & 1,473 \\
\hline Mehlich-3 extractable & & 37 \\
\hline Olsen extractable phos & & 21 \\
\hline AB-DTPA extractable & Phosphorus (mg. $\left.\mathrm{kg}^{-1}\right)$ & 15 \\
\hline & Potassium $\left(\mathrm{mg} \cdot \mathrm{kg}^{-1}\right)$ & 82 \\
\hline & Iron $\left(\mathrm{mg} \cdot \mathrm{kg}^{-1}\right)$ & 6 \\
\hline & Zinc $\left(\mathrm{mg} \cdot \mathrm{kg}^{-1}\right)$ & 7 \\
\hline & Manganese $\left(\mathrm{mg} \cdot \mathrm{kg}^{-1}\right)$ & 11 \\
\hline
\end{tabular}

AB-DTPA $=$ ammonium bicarbonate-diethylenetriaminepentaacetic acid .

Table 2. Summary of cultural practices used for evaluating phosphorus application rates on tomato grown during 2014 and 2015 winter seasons.

\begin{tabular}{|c|c|c|c|}
\hline \multicolumn{2}{|c|}{ Cultural practice } & 2014 & 2015 \\
\hline \multirow{2}{*}{\multicolumn{2}{|c|}{$\begin{array}{l}\text { Plot size } \\
\text { Bed spacing (center to center) }\end{array}$}} & \multicolumn{2}{|c|}{$9.1 \mathrm{~m}$ length $\times 5.5 \mathrm{~m}$ wide (included three beds) } \\
\hline & & \multicolumn{2}{|c|}{$183 \mathrm{~cm}$} \\
\hline \multicolumn{2}{|l|}{ Bed height } & \multicolumn{2}{|c|}{$20 \mathrm{~cm}$} \\
\hline \multicolumn{2}{|l|}{ Bed width } & \multicolumn{2}{|c|}{$91 \mathrm{~cm}$} \\
\hline \multicolumn{2}{|c|}{ Irrigation type } & \multicolumn{2}{|c|}{ Drip } \\
\hline \multicolumn{2}{|l|}{ Fumigation } & \multicolumn{2}{|c|}{ No } \\
\hline \multicolumn{2}{|c|}{$\begin{array}{l}\text { Mulch laying and fertilizer } \\
\text { application date }\end{array}$} & 29 Oct. 2014 & 15 Oct. 2015 \\
\hline \multicolumn{2}{|c|}{ Polyethylene mulch } & \multicolumn{2}{|c|}{$\begin{array}{c}\text { Guardian Standard white on black (Guardian Agricultural } \\
\text { Plastics Corp., SC) }\end{array}$} \\
\hline \multicolumn{2}{|l|}{ Drip tape } & \multicolumn{2}{|c|}{$\begin{array}{l}1.6 \mathrm{~cm} \text { diameter with } 20 \mathrm{~cm} \text { emitter spacing and a flow rate of } \\
4.2 \mathrm{~L} \mathrm{~min}^{-1} 100 \mathrm{~m}^{-1} \text { at } 55 \mathrm{kPa} \text { (T-Systems International Inc., CA) }\end{array}$} \\
\hline \multicolumn{2}{|c|}{ Tomato cultivar } & \multicolumn{2}{|c|}{ Ridgerunner (Syngenta, NC) } \\
\hline \multicolumn{2}{|c|}{ Transplanting date } & \multicolumn{2}{|r|}{23 Oct. 2015} \\
\hline \multicolumn{2}{|c|}{ Plant spacing } & \multicolumn{2}{|c|}{$46 \mathrm{~cm}$} \\
\hline \multicolumn{2}{|c|}{ Plant population } & \multicolumn{2}{|c|}{$11,960 \mathrm{plant} / \mathrm{ha}$} \\
\hline \multicolumn{2}{|c|}{ Harvest unit } & \multicolumn{2}{|c|}{10 plants in the middle bed of each plot } \\
\hline \multirow[t]{3}{*}{ Harvest date } & First & 25 Feb. 2015 & 19 Jan. 2016 \\
\hline & Second & 11 Mar. 2015 & 2 Feb. 2016 \\
\hline & Third & 24 Mar. 2015 & 16 Feb. 2016 \\
\hline
\end{tabular}

acid (Mylavarapu et al., 2014) and analyzed for LTPC through Inductively Coupled Plasma-Optical Emission Spectroscopy (Optima 7000 DV ICP-OES; PerkinElmer Inc., Waltham, MA). Those LTPCs were evaluated according to the adequate range in tomato production (Hochmuth et al., 2012). Tomato fruits were harvested at the mature-green stage at 111,125 , and 138 DAT in 2014 and 88, 102, and 116 DAT in 2015 as the first, second, and third harvest, respectively. Marketable fruits were categorized as extralarge (diameter larger than $7 \mathrm{~cm}$ ), large (diameter from 6.4 to $7.1 \mathrm{~cm}$ ), and medium (diameter from 5.7 to $6.4 \mathrm{~cm}$ ) fruits (U.S. Department of Agriculture, 1997). Unmarketable fruits were recognized based on the presence of the rough blossom-end scar (catface), cracking (concentric and radial), offshape, zipper scars, sunscald, and other viral and pest damages (Barten et al., 1992; Olson and Freeman, 2016). At the first harvest, ten mature-green fruits from each plot were collected, treated with ethylene and ripened at $20{ }^{\circ} \mathrm{C}$ with $85 \%$ to $90 \%$ relative humidity in DiMare's packing house (Homestead, FL).
After reaching breaker stage, tomatoes were moved out of the packing house and ripened at room temperature $\left(23\right.$ to $24{ }^{\circ} \mathrm{C}$ ) to the tableripe stage (defined as "the point at which redripe tomatoes become noticeably softer when pressure is applied with thumb and fingertips to the equatorial region of each fruit") for postharvest evaluation (Frasca and OzoresHampton, 2014). Fruit firmness was tested as deformation using an 11-mm probe and 1-kg force applied to the fruit equator area for $5 \mathrm{~s}$ by a portable digital firmness tester (Model C125EB; Mitutoyo Corp., Aurora, IL); fruit exterior color was measured using a 1 to 6 scale where $1=$ green and $6=$ red (U.S. Department of Agriculture, 1997); total soluble solids (TSS) at $20{ }^{\circ} \mathrm{C}$, and $\mathrm{pH}$ were measured by a portable refractometer (Fisher Catalog Number 13-946-26; Fisher Scientific, Pittsburgh, PA) and a $\mathrm{pH}$ meter (Accumet AR 60; Fisher Scientific), respectively.

Leaf tissue $\mathrm{P}$ concentrations, plant growth parameters (plant height, stem diameter, and SPAD value), biomass, yield, and postharvest quality assessments were first subjected to a two-way analysis of variance (ANOVA) 
using SAS (Version 9.2; SAS Institute Inc., Cary, NC). Year, P rate, and the interaction of year and $P$ rate were included as fixed effects. If the effect of either the year or the interaction was significant, the data from each year were analyzed separately by a one-way ANOVA regarding $P$ rate as the fixed effect. When $\mathrm{F}$ test showed statistical significance $(P<0.05)$, the responses to $\mathrm{P}$ rates were analyzed by SAS using four regression models: linear, quadratic, linear-plateau ( $y=a+b x$ if $x<$ critical rate, $y=$ plateau if $x>$ critical rate), and quadratic-plateau ( $y=$ $a+b x+c x^{2}$ if $x<$ critical rate, $y=$ plateau if $x>$ critical rate), where $y$ was the response, $x$ was $\mathrm{P}$ rate, and $a, b$, and $c$ were constants. The best fit model was selected based on $P<0.05$, lower mean square error, and higher coefficient of determination $\left(r^{2}\right)$ (OzoresHampton et al., 2012). The critical rates in linear-plateau and quadratic-plateau models and the rate at which the maximum dependent variable occurred in quadratic model were considered as optimum rates.

\section{Results}

In 2014, the average daily $60-\mathrm{cm}$ air and $10-\mathrm{cm}$ soil temperatures from 1 to 30 DAT were $4{ }^{\circ} \mathrm{C}$ lower than those in 2015 , which were 25 and $27^{\circ} \mathrm{C}$, respectively. From 31 to $60 \mathrm{DAT}$, the average air and soil temperatures in 2014 were 4 and $2{ }^{\circ} \mathrm{C}$ lower than the values of 23 and $24^{\circ} \mathrm{C}$ in 2015 , respectively. From 61 to 95 DAT, the average air temperature in 2014 was $1{ }^{\circ} \mathrm{C}$ lower than that in 2015 , and the average soil temperatures were the same between the two years. The rainfall accumulations from 1 to 30 DAT were similar between 2014 and 2015 with 41 and $38 \mathrm{~mm}$, respectively. However, the rainfall accumulations from 31 to 60 DAT and 61 to 95 DAT in 2015 were 26 and 6 times higher than those in 2014, which were 12 and $21 \mathrm{~mm}$, respectively.

Although the interaction effect between year and P rate was not significant for LTPC, the main effect of year was significant, thus, the LTPCs were analyzed separately by year (Table 3). No significant differences were found in LTPC among P rates at 30,60, and 95 DAT in either year. Without $\mathrm{P}$ fertilization,

Table 3. Leaf tissue phosphorus $(\mathrm{P})$ concentrations in response to $\mathrm{P}$ rates for tomato grown in 2014 and 2015 winter seasons.

\begin{tabular}{|c|c|c|c|c|c|c|}
\hline \multirow[b]{3}{*}{$P$ rate } & \multicolumn{6}{|c|}{ Days after transplanting } \\
\hline & \multicolumn{2}{|c|}{30} & \multicolumn{2}{|c|}{60} & \multicolumn{2}{|c|}{95} \\
\hline & 2014 & 2015 & $\overline{2014}$ & 2015 & 2014 & 2015 \\
\hline$\overline{\left(\mathrm{kg} \cdot \mathrm{ha}^{-1}\right)}$ & \multicolumn{6}{|c|}{$\left(\mathrm{g} \cdot \mathrm{kg}^{-1}\right)$} \\
\hline 0 & 2.8 & 1.9 & 1.8 & 2.4 & 1.6 & 2.4 \\
\hline 29 & 2.6 & 2.0 & 2.0 & 2.6 & 1.8 & 2.5 \\
\hline 49 & 2.9 & 2.8 & 2.1 & 2.3 & 1.5 & 2.4 \\
\hline 78 & 2.8 & 2.5 & 2.4 & 2.5 & 1.7 & 2.4 \\
\hline 98 & 2.6 & 2.7 & 2.9 & 2.4 & 1.5 & 2.5 \\
\hline 118 & 2.7 & 2.8 & 2.0 & 2.5 & 1.6 & 2.6 \\
\hline$P$ value & 0.76 & 0.10 & 0.12 & 0.17 & 0.05 & 0.14 \\
\hline Significance & NS & NS & NS & NS & NS & NS \\
\hline Adequate range ${ }^{\mathrm{z}}$ & \multicolumn{2}{|c|}{$2.0-4.0$} & \multicolumn{2}{|c|}{$2.0-4.0$} & \multicolumn{2}{|c|}{$2.0-4.0$} \\
\hline
\end{tabular}

${ }^{\mathrm{z}}$ Hochmuth et al. (2012).

$\mathrm{NS}=$ nonsignificant.

deficient levels of LTPC were observed at 30 DAT in 2015 and 60 DAT in 2014. Adequate LTPCs were found at 30 and 60 DAT with P rates from 29 to $118 \mathrm{~kg} \cdot \mathrm{ha}^{-1}$ in both years. At 95 DAT, LTPCs in all treatments were below the sufficient level of $2 \mathrm{~g} \cdot \mathrm{kg}^{-1}$ and averaged $1.6 \mathrm{~g} \cdot \mathrm{kg}^{-1}$ in 2014 , whereas all the LTPCs were above the sufficient level and averaged $2.5 \mathrm{~g} \cdot \mathrm{kg}^{-1}$ in 2015 .

The interaction effect between year and $\mathrm{P}$ rate was significant for plant height and SPAD value at $30 \mathrm{DAT}$, and the main effect of year was significant for plant height, stem diameter, and SPAD value at all sampling dates, thus, plant growth data were analyzed separately by year (Table 4). Plant height, stem diameter, and SPAD values at 30 DAT were not significantly affected by $P$ rates in 2014. In 2015, however, those responses were predicted by quadratic-plateau, quadraticplateau, and quadratic models with optimum $P$ rates of 87,66 , and $78 \mathrm{~kg} \cdot \mathrm{ha}^{-1}$, respectively. At 60 DAT, there were no significant differences in those plant growth parameters among $\mathrm{P}$ rates in either year. Plant height, stem diameter, and SPAD value at 60 DAT averaged $87 \mathrm{~cm}, 14 \mathrm{~mm}$, and 55 and $111 \mathrm{~cm}, 15 \mathrm{~mm}$, and 47 in 2014 and 2015 , respectively. No significant differences were found in plant height and stem diameter at 95 DAT in either year. The response of the SPAD value at 95 DAT was predicted by a quadratic model with an optimum $P$ rate of $53 \mathrm{~kg} \cdot \mathrm{ha}^{-1}$ in 2014 , but in 2015 , those values were not significantly affected by $P$ rates.

A significant main effect of year was found for plant (root, stem, and leaf combined), fruit, and total (plant and fruit combined) biomasses, thus, biomass data were analyzed separately by year (Table 5). No significant differences were found in plant biomass among P rates at 30 DAT in 2014. Nevertheless, the plant biomass at 30 DAT increased linearly with increasing $\mathrm{P}$ rate in 2015. At 60 DAT, plant and total biomasses increased linearly with increasing $\mathrm{P}$ rate in 2014 , but not in 2015. The response of fruit biomass at 60 DAT was described by a linearplateau model with critical $P$ rate of $91 \mathrm{~kg} \cdot \mathrm{ha}^{-1}$ in 2014 , whereas that response was nonsignificant in 2015. Plant biomasses at 95 DAT were not significantly affected by
$\mathrm{P}$ rates and averaged 3424 and $3391 \mathrm{~kg} \cdot \mathrm{ha}^{-1}$ in 2014 and 2015, respectively. The proportion of fruit in total biomass at 95 DAT ranged from $53 \%$ to $60 \%$ and $31 \%$ to $39 \%$ with an average of 55\% and 34\% in 2014 and 2015 , respectively. In 2014, the fruit and total biomasses at 95 DAT were not significantly affected by $\mathrm{P}$ rates. In 2015, however, the responses of fruit and total biomasses at 95 DAT were predicted by linear-plateau and quadratic-plateau models with critical $P$ rates of 64 and $77 \mathrm{~kg} \cdot \mathrm{ha}^{-1}$, respectively.

The main effect of year was significant for marketable and unmarketable yield at the three harvests, thus, yield data were analyzed separately by year (Table 6). At the first harvest, extralarge fruits accounted for $90 \%$ to $95 \%$ and $71 \%$ to $86 \%$ of the total marketable yield (TMY) in 2014 and 2015, respectively. The extralarge fruit yield and TMY at the first harvest increased linearly with increasing $\mathrm{P}$ rate, but no significant differences were found in large and medium fruits and unmarketable yields in 2014. In 2015, the responses of extralarge fruit yield and TMY at the first harvest were predicted by quadratic-plateau models with critical rates of 70 and $78 \mathrm{~kg} \cdot \mathrm{ha}^{-1}$, respectively. The large fruit and unmarketable yields at the first harvest of 2015 were significantly affected by $P$ rates, and the responses were described by linear-plateau and linear models, respectively. No significant responses to $\mathrm{P}$ rates were found in all the yield categories of the first and second combined harvest in 2014. However, quadratic-plateau and linearplateau models predicted the extralarge fruit yield and TMY at the first and second combined harvest of 2015 with critical P rates of 75 and $56 \mathrm{~kg} \cdot \mathrm{ha}^{-1}$, respectively. At the total season harvest (three harvests combined), the extralarge, large, and medium fruits accounted for $79 \%$ to $84 \%, 12 \%$ to $15 \%$, and $4 \%$ to $7 \%$ and for $23 \%$ to $56 \%$, $23 \%$ to $35 \%$, and $23 \%$ to $43 \%$ of TSMY in 2014 and 2015, respectively. All the yield categories at the total season harvest were not significantly affected by $\mathrm{P}$ rates and the TSMY averaged $79 \mathrm{t} \cdot \mathrm{ha}^{-1}$ in 2014. In 2015, the extralarge fruit yield increased quadratically with increasing $\mathrm{P}$ rate and reached a maximum at $74 \mathrm{~kg} \cdot \mathrm{ha}^{-1}$, whereas the medium fruit yield decreased quadratically and reached a minimum at $64 \mathrm{~kg} \cdot \mathrm{ha}^{-1}$. No significant differences were found in large fruits yield, TSMY, and unmarketable yield at the total season harvest in 2015 and the TSMY averaged $33 \mathrm{t} \cdot \mathrm{ha}^{-1}$. Neither the interaction effect between year and $P$ rate nor the main effect of year was significant; thus, the data of postharvest qualities from each year were combined for analysis (Table 7). Tomato postharvest qualities, including firmness, exterior color, $\mathrm{pH}$, and TSS content, were not significantly affected by $P$ rates.

\section{Discussion}

Leaf tissue $\mathrm{P}$ concentrations were not significantly affected by $\mathrm{P}$ rates ranging from 0 to $118 \mathrm{~kg} \cdot \mathrm{ha}^{-1}$ during the two tomato 
Table 4. Plant height $(\mathrm{cm})$, stem diameter (mm), and leaf chlorophyll content [represented as Soil Plant Analysis Development (SPAD) value] in response to phosphorus $(\mathrm{P})$ rates for tomato grown in 2014 and 2015 winter seasons.

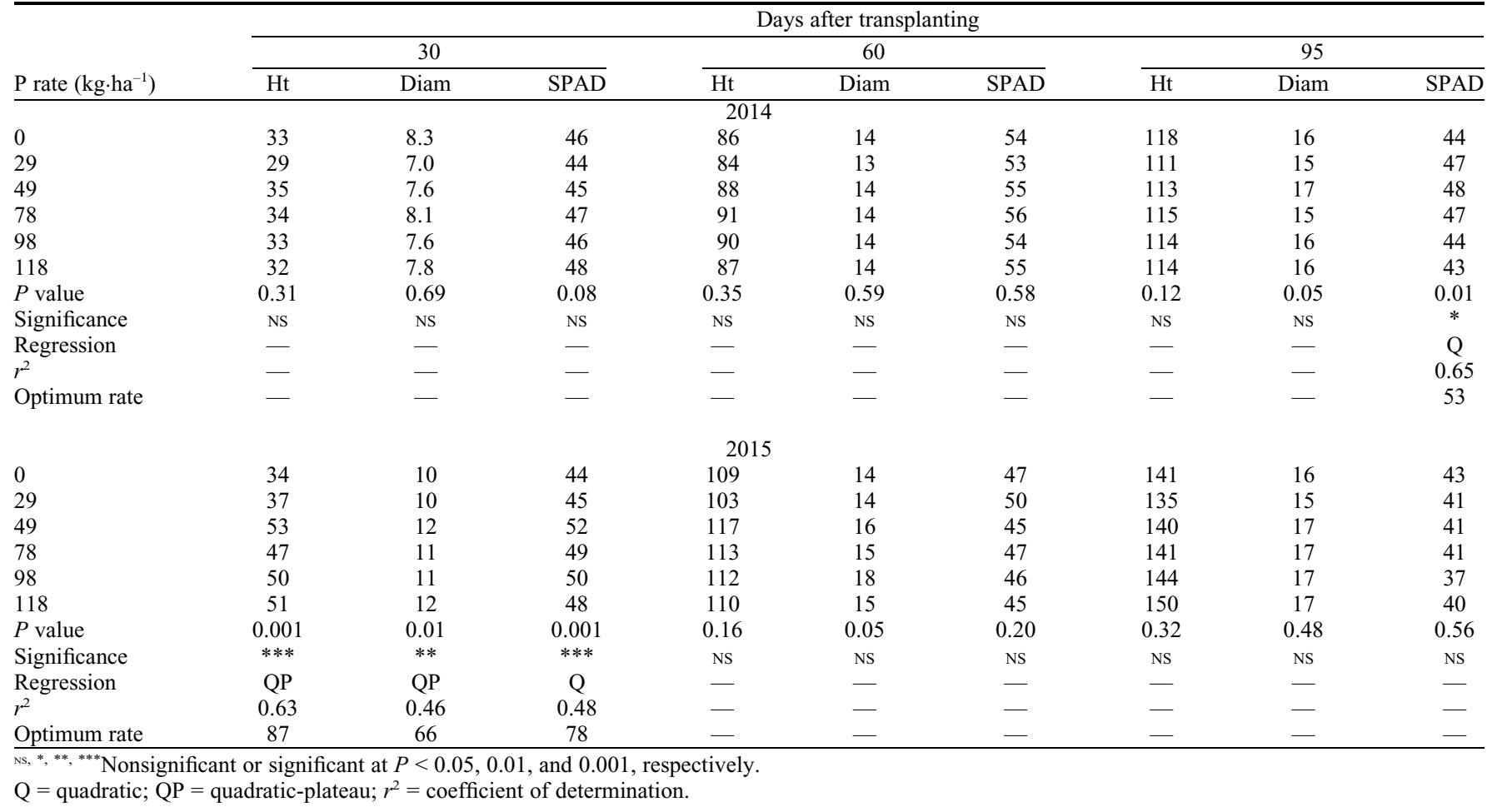

Table 5. Plant (root, stem, and leaf combined), fruit, and total (plant and fruit) dry weight biomass in response to phosphorus (P) rates for tomato grown in 2014 and 2015 winter seasons.

\begin{tabular}{|c|c|c|c|c|c|c|c|}
\hline \multirow[b]{3}{*}{$\underline{P \text { rate }}$} & \multicolumn{7}{|c|}{ Days after transplanting } \\
\hline & $\frac{30}{\text { Plant }}$ & \multicolumn{3}{|c|}{60} & \multicolumn{3}{|c|}{95} \\
\hline & \multicolumn{7}{|c|}{$\left(\mathrm{kg} \cdot \mathrm{ha}^{-1}\right)$} \\
\hline 0 & 112 & 1,192 & 91 & 1,282 & 3,322 & 3,871 & 7,193 \\
\hline 29 & 86 & 908 & 26 & 934 & 3,597 & 4,153 & 7,750 \\
\hline 49 & 122 & 1,321 & 114 & 1,435 & 3,459 & 4,395 & 7,854 \\
\hline 78 & 135 & 1,764 & 198 & 1,962 & 3,070 & 4,638 & 7,708 \\
\hline$P$ value & 0.38 & 0.002 & 0.001 & 0.001 & 0.50 & 0.43 & 0.81 \\
\hline Significance & NS & $* *$ & $* * *$ & $* *$ & NS & NS & NS \\
\hline Regression & - & $\mathrm{L}$ & LP & $\mathrm{L}$ & - & - & - \\
\hline$r^{2}$ & - & 0.45 & 0.39 & 0.43 & - & - & - \\
\hline \multirow[t]{2}{*}{ Optimum rate } & - & - & 91 & - & - & - & - \\
\hline & & & & 2015 & & & \\
\hline 98 & 388 & 2,220 & 359 & 2,580 & 3,174 & 1,714 & 4,888 \\
\hline 118 & 349 & 2,505 & 794 & 3,299 & 3,953 & 1,803 & 5,756 \\
\hline$P$ value & 0.01 & 0.30 & 0.16 & 0.16 & 0.12 & 0.001 & 0.02 \\
\hline Significance & $* *$ & NS & NS & NS & NS & $* * *$ & $*$ \\
\hline Regression & $\mathrm{L}$ & - & - & - & - & LP & QP \\
\hline$r^{2}$ & 0.58 & - & - & - & - & 0.64 & 0.36 \\
\hline Optimum rate & - & - & - & - & - & 64 & 77 \\
\hline
\end{tabular}

Ns, ${ }^{*}, * *, * * *$ Nonsignificant or significant at $P<0.05,0.01$, and 0.001 , respectively.

$\mathrm{L}=$ linear; $\mathrm{LP}=$ linear-plateau; $\mathrm{QP}=$ quadratic-plateau; $r^{2}=$ coefficient of determination.

growing seasons. Li et al. (2000) also found $\mathrm{P}$ rates from 10 to $116 \mathrm{~kg} \cdot \mathrm{ha}^{-1}$ had no significant effect on LTPC of potato in calcareous soils with $57 \mathrm{mg} \cdot \mathrm{kg}^{-1}$ of AB-DTPA extractable $\mathrm{P}$ in Florida. Nonetheless, in neutral-mineral soils with very high Mehlich-1 extractable P, LTPCs were shown to increase linearly or

HortScience Vol. 52(10) October 2017 quadratically with increasing $\mathrm{P}$ rate from 0 to 99 or $200 \mathrm{~kg} \cdot \mathrm{ha}^{-1}$ during tomato growing seasons in Florida (Hochmuth et al., 1999; Shuler and Hochmuth, 1995). Nonsignificant responses of LTPC might be attributed to the limited impacts of $\mathrm{P}$ fertilization on soluble $\mathrm{P}$ in calcareous soils comparing with neutral-mineral soils. Dissolved P from fertilizer could be rapidly fixed by surface adsorption and precipitation due to the presence of free calcium carbonate (von Wandruszka, 2006; Zhou and Li, 2001). Because there were limited increases in soil solution $\mathrm{P}$ that served as sources for plant uptake, the 
Table 6. Effect of phosphorus $(\mathrm{P})$ rates on tomato marketable and unmarketable yield at the first, first and second combined, and total season (three harvests combined) harvests in 2014 and 2015 winter seasons.

\begin{tabular}{|c|c|c|c|c|c|c|c|c|c|c|c|c|c|c|c|}
\hline \multirow[b]{2}{*}{$\mathrm{P}$ rate } & \multicolumn{5}{|c|}{ First harvest } & \multicolumn{5}{|c|}{ First and second harvest } & \multicolumn{5}{|c|}{ Total season harvest } \\
\hline & $\mathrm{XL}^{\mathrm{z}}$ & $\mathrm{L}$ & M & TMY & $\mathrm{U}$ & $\mathrm{XL}$ & $\mathrm{L}$ & $\mathrm{M}$ & TMY & $\mathrm{U}$ & $\mathrm{XL}$ & $\mathrm{L}$ & M & TSMY & $\mathrm{U}$ \\
\hline 49 & 43 & 3.9 & 0.2 & 47 & 15 & 57 & 7.6 & 0.9 & 65 & 25 & 59 & 9.7 & 3.4 & 72 & 32 \\
\hline 78 & 48 & 3.3 & 0.0 & 52 & 13 & 64 & 6.7 & 0.9 & 72 & 23 & 67 & 9.4 & 3.7 & 80 & 34 \\
\hline 98 & 46 & 2.9 & 0.3 & 49 & 11 & 63 & 6.6 & 1.7 & 72 & 20 & 66 & 9.9 & 4.7 & 80 & 27 \\
\hline Significance & * & NS & NS & * & NS & NS & NS & NS & NS & NS & NS & NS & NS & NS & NS \\
\hline Regression $^{y}$ & L & - & - & L & - & & & - & - & - & - & - & - & - & - \\
\hline$r^{2}$ & 0.31 & - & - & 0.33 & - & - & - & - & - & - & - & - & - & - & - \\
\hline \multirow[t]{2}{*}{ Optimum rate } & - & - & - & - & - & - & - & - & 一 & - & - & - & - & - & - \\
\hline & \multicolumn{15}{|c|}{2015} \\
\hline 0 & 3 & 0.9 & 0.1 & 4 & 1.5 & 6 & 4.4 & 3.9 & 14 & 4.4 & 7 & 10.8 & 13.3 & 31 & 7.0 \\
\hline 118 & 12 & 3.4 & 1.2 & 17 & 8.0 & 15 & 6.1 & 3.4 & 25 & 10.7 & 16 & 9.5 & 9.5 & 34 & 13.1 \\
\hline$P$ value & 0.001 & 0.02 & 0.08 & 0.001 & 0.04 & 0.001 & 0.16 & 0.49 & 0.001 & 0.10 & 0.001 & 0.23 & 0.04 & 0.47 & 0.24 \\
\hline Significance & $* * *$ & $*$ & NS & $* * *$ & $*$ & $* * *$ & NS & NS & $* * *$ & NS & $* * *$ & NS & $*$ & NS & NS \\
\hline Regression $^{y}$ & QP & LP & - & QP & $\mathrm{L}$ & QP & - & - & LP & - & QP & - & QP & - & - \\
\hline$r^{2}$ & 0.57 & 0.43 & - & 0.58 & 0.30 & 0.65 & - & - & 0.63 & - & 0.67 & - & 0.31 & - & - \\
\hline Optimum rate & 70 & 105 & - & 78 & - & 75 & - & - & 56 & - & 74 & - & 64 & - & - \\
\hline
\end{tabular}

${ }^{\mathrm{z}} \mathrm{XL}=$ extralarge $(>7 \mathrm{~cm}), \mathrm{L}=$ large $(6.4-7.1 \mathrm{~cm}), \mathrm{M}=$ medium $(5.7-6.4 \mathrm{~cm}), \mathrm{TMY}=$ total marketable yield, $\mathrm{U}=$ unmarketable, $\mathrm{TSMY}=$ total season marketable yield.

${ }^{\mathrm{y}} \mathrm{L}=$ linear; $\mathrm{QP}=$ quadratic-plateau; $\mathrm{LP}=$ linear-plateau; $r^{2}=$ coefficient of determination.

Ns, *, *** Nonsignificant or significant at $P<0.05$ and 0.001 , respectively.

Table 7. Postharvest evaluation of tomato fruit firmness (represented as deformation), exterior color, $\mathrm{pH}$, and total soluble solids (TSS) after the first harvest for tomato grown with different phosphorus (P) rates in winter seasons.

\begin{tabular}{|c|c|c|c|c|}
\hline$\overline{\mathrm{P} \text { rate }\left(\mathrm{kg} \cdot \mathrm{ha}^{-1}\right)}$ & Deformation $^{z}(\mathrm{~mm})$ & Exterior color $^{\mathrm{y}}$ & $\mathrm{pH}$ & TSS ( ${ }^{\circ}$ Brix $)$ \\
\hline$\overline{0}$ & 2.8 & 4.8 & 4.4 & 3.7 \\
\hline 29 & 2.5 & 5.2 & 4.4 & 3.7 \\
\hline 49 & 2.5 & 5.1 & 4.3 & 3.8 \\
\hline 78 & 2.8 & 5.3 & 4.3 & 3.7 \\
\hline 98 & 2.5 & 5.0 & 4.4 & 3.8 \\
\hline 118 & 2.6 & 5.2 & 4.4 & 3.9 \\
\hline$P$ value & 0.37 & 0.40 & 0.22 & 0.23 \\
\hline Significance & NS & NS & NS & NS \\
\hline
\end{tabular}

absorbed P was mainly used for biomass accumulation or $\mathrm{P}$ accumulation in fruits rather than in leaves; thus, the LTPC did not significantly increase as P rates increased during the growing season.

Carrijo and Hochmuth (2000) found zero $\mathrm{P}$ fertilization resulted in deficient tomato LTPC at 88 DAT in acid-mineral soils with either high or very low Mehlich-1 extractable $\mathrm{P}$ in Florida. In the present study, deficient LTPC occurred at 60 and 95 DAT in 2014 whereas only at 30 DAT in 2015 for the zero $P$ treatment. At 30 DAT in 2014, adequate LTPC in all treatments in combination with unaffected plant growth parameters and plant biomass indicated that the initial STP concentrations were sufficient for tomato early growth. At 60 DAT in 2014, although there were no significant differences in plant growth parameters, deficient LTPC was observed in zero $\mathrm{P}$ treatment, and the plant biomass increased linearly with increasing $\mathrm{P}$ rate. These results showed that with plant growth, additional $\mathrm{P}$ was progressively provided by fertilizer sources. Nevertheless, at 95 DAT in 2014, the improvement effect of $\mathrm{P}$ fertilization on plant biomass was not significant, and deficient LTPCs were observed in all treatments, suggesting the impacts of $\mathrm{P}$ fertilization on LTPC and biomass accumulation did not remain until 95 DAT. These findings were supported by Castro and Torrent (1995), which found that the availability of applied $\mathrm{P}$ decreased with time during the showed that a $\mathrm{P}$ application rate of $90 \mathrm{~kg} \cdot \mathrm{ha}^{-1}$ increased processing tomato plant biomass (stem and leaf combined) by only $9 \%$ comparing with $0 \mathrm{~kg} \cdot \mathrm{ha}^{-1}$ at the end of growing season in acid to neutral-mineral soils with growing season. Similarly, Liu et al. (2011) medium to high levels of Olsen extractable $\mathrm{P}$. At 95 DAT in 2014, the decreased SPAD value with $\mathrm{P}$ rates higher than $78 \mathrm{~kg} \cdot \mathrm{ha}^{-1}$ might be attributed to the reduced uptake and translocation of iron $(\mathrm{Fe})$ as indicated by Mengel and Kirkby (1987).

In 2015, deficient LTPC was found at 30 DAT but not at 60 and 95 DAT for the zero $P$ treatment. In addition, $P$ rates of 0 and 29 $\mathrm{kg} \cdot \mathrm{ha}^{-1}$ resulted in significantly lower plant height and leaf chlorophyll content than other rates and plant biomass increased linearly with increasing $P$ rate at 30 DAT in 2015 . The crop responses to $P$ rates were affected by the initial STP as well as soil temperature, which influenced soil microbial activity, root metabolism, and P diffusion (Havlin et al., 2005; Potash and Phosphate Institute, 1999b). Thus, the availability of $\mathrm{P}$ after fertilization was improved by the higher soil temperature from 1 to 30 DAT in 2015. Meanwhile, the higher plants and larger stem diameters indicated plant growth was faster within the first $30 \mathrm{~d}$ in 2015 than in 2014, which was probably due to the higher air temperature. Mengel and Kirkby (1987) revealed that there was a relatively high crop $\mathrm{P}$ requirement at early growth stages. Sainju et al. (2003) also concluded adequate $\mathrm{P}$ nutrition enhanced early plant establishment of tomato. Therefore, supplemental $\mathrm{P}$ at and below $29 \mathrm{~kg} \cdot \mathrm{ha}^{-1}$ could not provide as much $\mathrm{P}$ as other higher rates for plant growth, and the optimum $P$ rates were predicted to be 66 to $87 \mathrm{~kg} \cdot \mathrm{ha}^{-1}$ based on the plant growth parameters at 30 DAT in 2015. According to Raghothama and Karthikeyan (2005) and 
Vance et al. (2003), plants have ability to acquire adequate $\mathrm{P}$ in P-limiting conditions by modifying root morphology and architecture. As a result, no deficient LTPC and no significant differences were observed in plant growth parameters and plant biomass among $P$ rates at 60 and 95 DAT in 2015.

The deficient levels of LTPC with all P rates at 95 DAT in 2014 were due to the translocation of larger amount of $\mathrm{P}$ from leaves to fruits comparing with 2015, which was confirmed by the fruit biomass. At 95 DAT, plant biomasses were similar between the two years, but the fruit biomasses in 2014 were higher than those in 2015 at equivalent $P$ rates. The faster plant growth rate resulted in a 22-d shorter-growing season in 2015 compared with 2014 . Yield potential of nonperennial crops could be depressed by shorter life cycle (Hatfield and Prueger, 2015). In addition, higher rainfall accumulation from 31 to 95 DAT adversely affected tomato pollination and fruit development (OzoresHampton and McAvoy, 2015). Consequently, the fruit and total biomasses at 95 DAT were lower in 2015 than in 2014. Fruit biomasses at 95 DAT were significantly affected in 2015 but not in 2014, which could be explained by an increased resistance to adverse weather conditions as a result of $P$ fertilization in 2015.

The initial STP levels in this study were categorized as very high and high adopting the AB-DTPA and Olsen interpretations for Colorado calcareous soils (Self, 2000), respectively. Wiedenfeld and Provin (2010) found no yield response of corn (Zea mays L.) to $\mathrm{P}$ rates ranging from 0 to $73 \mathrm{~kg} \cdot \mathrm{ha}^{-1}$ in a calcareous soil with higher than $60 \mathrm{mg} \cdot \mathrm{kg}^{-1}$ of Mehlich-3 extractable P. In addition, P rates of 10 to $116 \mathrm{~kg} \cdot \mathrm{ha}^{-1}$ did not significantly affect potato tuber yield in calcareous soils with $57 \mathrm{mg} \cdot \mathrm{kg}^{-1}$ of AB-DTPA extractable P in Florida ( $\mathrm{Li}$ et al., 2000). Similarly, no significant responses of tomato TSMY to P rates were found in this study. However, there were significant responses at the first harvest of both years. The extralarge fruit yield and TMY at the first harvest of 2014 increased linearly with increasing $\mathrm{P}$ rate, which followed the same pattern of total biomass accumulation at 60 DAT in 2014 . Carrijo and Hochmuth (2000) also showed linear responses of extralarge fruit yield and TSMY to $\mathrm{P}$ rates from 0 to $100 \mathrm{~kg} \cdot \mathrm{ha}^{-1}$ in acid-mineral soils with very low Mehlich-1 extractable P. Nonetheless, no significant yield responses were observed at the first and second combined and total season harvests in 2014. These results supported the conclusion that the impacts of $\mathrm{P}$ fertilization were limited and could not continue until the late growth stage as discussed previously. In 2015 , under adverse weather conditions, $\mathrm{P}$ rates as high as 70 to $75 \mathrm{~kg} \cdot \mathrm{ha}^{-1}$ increased extralarge fruit yield from the first to the total season harvest, and P rates of 0 and $29 \mathrm{~kg} \cdot \mathrm{ha}^{-1}$ resulted in lower extralarge but higher medium fruit yield at the total season harvest. Because the TSMY were not significantly affected, the results indicated the delayed maturity at low
$P$ rates as identified by Potash and Phosphate Institute (1999a). Overall, using the extralarge fruit yield, which brought the highest return to grower (Pernezny et al., 1996), rather than the unaffected TSMY to calibrate $\mathrm{P}$ requirement appeared to be practical. Phosphorus recommendation for open field tomato production was reported as $55 \mathrm{~kg} \cdot \mathrm{ha}^{-1}$ in calcareous soils with lower than $50 \mathrm{mg} \cdot \mathrm{kg}^{-1}$ of Olsen extractable P (Zhang et al., 2007). In the calcareous soils of this study with extremely high carbonate content, $\mathrm{P}$ rate of $75 \mathrm{~kg} \cdot \mathrm{ha}^{-1}$ was predicted as sufficient rate based on the extralarge fruit yields in 2015 . These rates need to be validated by further studies with more growing seasons and various tomato varieties.

The lack of response of fruit firmness, exterior color, $\mathrm{pH}$, and TSS content to $\mathrm{P}$ rates might be due to the sufficient level of initial STP. Liu et al. (2011) showed P rates from 0 to $90 \mathrm{~kg} \cdot \mathrm{ha}^{-1}$ had no significant effects on the TSS content of processing tomato in acid to neutral-mineral soils with 37 to $65 \mathrm{mg} \cdot \mathrm{kg}^{-1}$ of Olsen extractable P. Similarly, Oke et al. (2005) found exterior color, $\mathrm{pH}$, and TSS content of processing tomato were not significantly affected by $\mathrm{P}$ rates ranging from 22 to $97 \mathrm{~kg} \cdot \mathrm{ha}^{-1}$ in sandy loam soils with 30 to $50 \mathrm{mg} \cdot \mathrm{kg}^{-1}$ of STP. Furthermore, in acidmineral soils with $6 \mathrm{mg} \cdot \mathrm{kg}^{-1}$ of Bray extractable $\mathrm{P}, 26 \mathrm{~kg} \cdot \mathrm{ha}^{-1}$ of $\mathrm{P}$ significantly increased tomato $\mathrm{pH}$ and TSS content comparing with 0 and $13 \mathrm{~kg} \cdot \mathrm{ha}^{-1}$, whereas no significant differences were found among $P$ rates above $26 \mathrm{~kg} \cdot \mathrm{ha}^{-1}$ (Adebooye et al., 2006). However, Carrijo and Hochmuth (2000) reported P rates from 0 to $100 \mathrm{~kg} \cdot \mathrm{ha}^{-1}$ did not significantly affect tomato $\mathrm{pH}$ and TSS content in acid-mineral soils with either high or low level of Mehlich-1 extractable P. Thus, besides preplant STP level, the response of tomato postharvest qualities to $\mathrm{P}$ rates might predominantly depend on tomato variety and growing season as revealed by Adebooye et al. (2006) and Hartz et al. (2001).

\section{Conclusions}

Results indicated the initial STP levels were sufficient for tomato early growth in 2014. In 2015, irrespective of the adequate initial STP, deficient LTPC was observed without $\mathrm{P}$ fertilization and plant biomass increased linearly with increasing $\mathrm{P}$ rate at 30 DAT, which could be attributed to the more rapid plant growth rate and higher soil temperature. The optimum $\mathrm{P}$ rates were predicted to be between 66 and $87 \mathrm{~kg} \cdot \mathrm{ha}^{-1}$ based on the plant growth parameters at 30 DAT in 2015. At 60 DAT in 2014, deficient LTPC was observed in zero P treatment, and plant biomass increased linearly with increasing $\mathrm{P}$ rate. Nonetheless, no deficient LTPC and no significant differences were observed in plant biomass among $\mathrm{P}$ rates at 60 DAT in 2015. The LTPC, plant height, stem diameter, and plant biomass at 95 DAT were not significantly affected by $\mathrm{P}$ rates in both years. The extralarge fruit yield at the first and second combined harvest was not significantly affected in 2014 , but the response was predicted by a quadratic-plateau model with critical rate of $75 \mathrm{~kg} \cdot \mathrm{ha}^{-1}$ in 2015. No significant responses of TSMY and postharvest qualities to $P$ rates were found in both years. Therefore, based on this study, the $P$ rate of $75 \mathrm{~kg} \cdot \mathrm{ha}^{-1}$ was considered adequate for tomato production on those calcareous soils.

\section{Literature Cited}

Adebooye, O.C., G.O. Adeoye, and H. TijaniEniola. 2006. Quality of fruits of three varieties of tomato (Lycopersicon esculentum L. Mill) as affected by phosphorus rates. J. Agron. 5:396400.

Barten, J.H.M., J.W. Scott, N. Kedar, and Y. Elkind. 1992. Low temperatures induce rough blossom-end scarring of tomato fruit during early flower development. J. Amer. Soc. Hort. Sci. 117:298-303.

Carrijo, O.A. and G. Hochmuth. 2000. Tomato responses to preplant-incorporated or fertigated phosphorus on soils varying in Mehlich-1 extractable phosphorus. HortScience 35:67-72.

Castro, B. and J. Torrent. 1995. Phosphate availability in calcareous Vertisols and Inceptisols in relation to fertilizer type and soil properties. Fert. Res. 40:109-119.

Florida Department of Agriculture and Consumer Services (FDACS). 2015. Water quality/ quantity best management practice for Florida vegetable and agronomic crops. 6 July 2016 $<$ http://www.freshfromflorida.com/content/ download/63017/1444054/VACBMP_FINAL_ 2015.pdf $>$.

Frasca, A.C. and M. Ozores-Hampton. 2014. Effects of plant population and breeding lines on fresh-market, compact growth habit tomatoes growth, flowering pattern, yield, and postharvest quality. HortScience 49:1529-1536.

Freeman, J.H., E.J. McAvoy, N. Boyd, P.J. Dittmar, M Ozores-Hampton, H.A. Smith, G.E. Vallad, and S.E. Webb. 2014a. Tomato production, p. 183204. In: G.E. Vallad, J.H. Freeman, and P.J. Dittmar (eds.). 2014-2015 Vegetable and small fruit production handbook of Florida. Vance Publishers, Lenexa, KS.

Freeman, J.H., G.E. Vallad, G. Liu, E.H. Simonne, G.J. Hochmuth, M.D. Dukes, L. Zotarelli, J.W. Noling, D.A. Botts, P.J. Dittmar, and S.A. Smith. 2014b. Vegetable production in Florida, p. 1-6. In: G.E. Vallad, J.H. Freeman, and P.J. Dittmar (eds.). 2014-2015 Vegetable and small fruit production handbook of Florida. Vance Publishers, Lenexa, KS.

Hartz, T.K., E.M. Miyao, R.J. Mullen, and M.D. Cahn. 2001. Potassium fertilization effects on processing tomato yield and fruit quality. Acta Hort. 542:127-133.

Hatfield, J.L. and J.H. Prueger. 2015. Temperature extremes: Effect on plant growth and development. Weather Clim. Extrem. 10:4-10.

Havlin, J.L., J.D. Beaton, S.L. Tisdale, and W.L. Nelson. 2005. Phosphorus, p. 160-198. In: Soil fertility and fertilizers: An introduction to nutrient management. Pearson Education Inc., Upper Saddle River, NJ.

Hochmuth, G., O. Carrijo, and K. Shuler. 1999 Tomato yield and fruit size did not respond to $\mathrm{P}$ fertilization of a sandy soil testing very high in Mehlich-1 P. HortScience 34:653-656.

Hochmuth, G., D. Maynard, C. Vavrina, E. Hanlon, and E. Simonne. 2012. Plant tissue analysis and interpretation for vegetable crops in Florida Univ. Florida, Inst. Food Agr. Sci., Electronic Data Info. Source. 10 July 2016. <http://edis. ifas.ufl.edu/ep081>. 
Lamberts, M., T. Olczyk, Y.C. Li, H.H. Bryan, M. Codallo, and L. Ramos. 1997. Field demonstrations of phosphorus levels for vine-ripe and mature-green tomatoes in Miami-Dade County. Proc. Annu. Meet. Fla. State Hort. Soc. 110: 266-268.

Li, Y.C., S. O'Hair, R. Mylavarapu, T. Olczyk, and M. Lamberts. 2000. Demonstration of phosphorus fertilizer management for potato grown in a calcareous soil. Proc. Annu. Meet. Fla. State Hort. Soc. 113:237-239.

Liu, K., T.Q. Zhang, C.S. Tan, and T. Astatkie. 2011. Responses of fruit yield and quality of processing tomato to drip-irrigation and fertilizers phosphorus and potassium. Agron. J. 103:1339-1345.

Mehlich, A. 1984. Mehlich 3 soil test extractant: A modification of Mehlich 2 extractant. Commun. Soil Sci. Plant Anal. 15:1409-1416.

Mengel, K. and E.A. Kirkby. 1987. Phosphorus, p. 403-420. In: Principles of plant nutrition. International Potash Institute, Bern, Switzerland.

Mylavarapu, R.S., W. d'Angelo, N. Wilkinson, and D. Moon. 2014. UF/IFAS Extension soil testing laboratory analytical procedures and training manual. Univ. Florida, Inst. Food Agr. Sci., Electronic Data Info. Source. 10 July 2016. $<$ http://edis.ifas.ufl.edu/ss312>.

Oke, M., T. Ahn, A. Schofield, and G. Paliyath. 2005. Effects of phosphorus fertilizer supplementation on processing quality and functional food ingredients in Tomato. J. Agr. Food Chem. 53:1531-1538.

Olczyk, T., Y. Li, E. Simonne, and R. Mylavarapu. 2003. Reduced phosphorus fertilization effects on yield and quality of sweet corn grown on a calcareous soil. Proc. Annu. Meet. Fla. State Hort. Soc. 116:95-97.

Olsen, S.R., C.V. Cole, F.S. Watanabe, and L.A. Dean. 1954. Estimation of available phosphorus in soils by extraction with sodium bicarbonate. USDA circular 939. U.S. Government Printing Office, Washington, DC.

Olson, S.M. and J. Freeman. 2016. Physiological, nutritional, and other disorders of tomato fruit.
Univ. Florida, Inst. Food Agr. Sci., Electronic Data Info. Source. HS954. 10 July 2016. $<$ http://edis.ifas.ufl.edu/hs200>.

Ozores-Hampton, M. and G. McAvoy. 2015. Blossom drop, reduced fruit set, and postpollination disorders in tomato. Univ. Florida, Inst. Food Agr. Sci., Electronic Data Info. Source. HS1195. 9 Feb. 2017. <http://edis. ifas.ufl.edu/hs1195>.

Ozores-Hampton, M., E. Simonne, F. Roka, K. Morgan, S. Sargent, C. Snodgrass, and E. McAvoy. 2012. Nitrogen rates effects on the yield, nutritional status, fruit quality, and profitability of tomato grown in the spring with subsurface irrigation. HortScience 47:1129-1135.

Pernezny, K., L.E. Datnoff, T. Mueller, and J. Collins. 1996. Losses in fresh-market tomato production in Florida due to target spot and bacterial spot and the benefits of protectant fungicides. Plant Dis. 80:559-563.

Potash and Phosphate Institute. 1999a. Functions of phosphorus in plants. Better Crops Plant Food 83:6-7.

Potash and Phosphate Institute. 1999b. Important factors affecting crop response to phosphorus. Better Crops Plant Food 83:16-18.

Raghothama, K.G. and A.S. Karthikeyan. 2005. Phosphate acquisition. Plant Soil 274:37-49.

Sainju, U.M., R. Dris, and B. Singh. 2003. Mineral nutrition of tomato. J. Food Agric. Environ 1:176-183.

Self, J. 2000. Phosphorus levels in Colorado soils, p. 7. In: R. Waskom, J. Stednick, and J. Davis (eds.). Agronomy News, Mar. 2000. Colorado State University, Fort Collins, CO.

Shuler, K. and G. Hochmuth. 1995. Field tests of phosphorus fertilization of tomato growing in high-P soils in Palm Beach County, Florida. Proc. Annu. Meet. Fla. State Hort. Soc. 108: 227-232.

Soltanpour, P.N. and A.P. Schwab. 1977. A new soil test for simultaneous extraction of macroand micro-nutrients in alkaline soils. Commun. Soil Sci. Plant Anal. 8:195-207.
U.S. Department of Agriculture (USDA). 1997. United States standards for grades of fresh tomatoes. USDA, Agriculture Marketing Service. Washington, DC. 30 May 2016. <https:// www.hort.purdue.edu/prod_quality/quality/ tomatfrh.pdf $>$.

U.S. Department of Agriculture (USDA). 2014. 2012 Census County-level data, Florida. USDA, Census of Agriculture, Washington, DC. 7 Oct. 2016. $<$ https://www.agcensus.usda.gov/Publications/ 2012/Full_Report/Volume_1,_Chapter_2_ County_Level/Florida/st12_2_029_029.pdf>.

U.S. Department of Agriculture (USDA). 2017. 2016 State agriculture overview Florida. USDA, National Agricultural Statistics Service, Washington, DC. 11 Apr. 2017. <https://www.nass.usda. gov/Quick_Stats/Ag_Overview/stateOverview. php?state=FLORIDA $>$.

Vance, C.P., C. Uhde-Stone, and D.L. Allan. 2003. Phosphorus acquisition and use: Critical adaptations by plants for securing a nonrenewable resource. New Phytol. 157:423-447.

von Wandruszka, R. 2006. Phosphorus retention in calcareous soils and the effect of organic matter on its mobility. Geochem. Trans. 7:6-14.

Wiedenfeld, B. and T. Provin. 2010. Corn responses to phosphorus application at different soil phosphorus levels on a calcareous soil. Commun. Soil Sci. Plant Anal. 41:1832-1837.

Zhang, X.S., H. Liao, Q. Chen, P. Christie, X.L. $\mathrm{Li}$, and F.S. Zhang. 2007. Response of tomato on calcareous soils to different seedbed phosphorus application rates. Pedosphere 17:70-76.

Zhou, M. and Y. Li. 2001. Phosphorus-sorption characteristics of calcareous soils and limestone from the southern Everglades and adjacent farmlands. Soil Sci. Soc. Amer. J. 65:1404-1412.

Zhu, Q., M. Ozores-Hampton, and Y. Li. 2016. Comparison of Mehlich-3 and ammonium bicarbonate-DTPA for the extraction of phosphorus and potassium in calcareous soils from Florida. Commun. Soil Sci. Plant Anal. 47: 2315-2324. 